\title{
Boehmite nanoparticle catalyst for the one-pot multicomponent synthesis of 3,4-dihydropyrimidin-2-(1H)-ones and thiones under solvent-free conditions
}

\author{
Ali Keivanloo *, Mahdi Mirzaee, Mohammad Bakherad, Atena Soozani \\ School of Chemistry, Shahrood University of Technology, Shahrood, Iran
}

\section{A R T I C L E I N F O}

Article history:

Received 22 August 2013

Accepted 25 November 2013

Published 20 March 2014

\section{Keywords:}

Boehmite nanoparticle

One-pot synthesis

Multicomponent synthesis

Dihydropyrimidine

Solvent-free

\section{A B S T R A C T}

A simple, green, and efficient synthesis protocol for the synthesis of 3,4-dihydropyrimidin-2-(1H)ones using boehmite nanoparticles as catalyst was developed. It did not use any toxic metal catalysts or corrosive acidic reagents. The method gave good to excellent yields and has short reaction time, operational simplicity, and a recyclable catalyst.

(C) 2014, Dalian Institute of Chemical Physics, Chinese Academy of Sciences. Published by Elsevier B.V. All rights reserved.

\section{Introduction}

Multicomponent reactions (MCRs) are powerful, versatile, and popular tools for the synthesis of novel and complex molecular structures that have advantages over a conventional multistep synthesis [1-3]. The major advantages of MCRs include lower cost, shorter reaction time, high atom economy, energy saving, and avoidance of time consuming and expensive purification [4-6]. MCRs are generally much more environmentally friendly, provide synthetic access to large compound libraries with diverse functionalities, and do not need protection and deprotection steps [7].

One of the most important MCRs is the Biginelli reaction. This reaction allows the synthesis of dihydropyrimidinones (DHPMs), which are compounds with anti-viral, anti-tumor, anti-bacterial, cytotoxic, and anti-flammatory properties [8]. DHPMs possess remarkable pharmacological efficiency, which is demonstrated by their utility as the integral backbones of calcium channel blockers $[9,10]$. The anti-cancer agent monastrol is the only cell-permeable molecule currently known to specifically inhibit mitotic kinesin Eg5 [11].

DHPMs are also prominent in SQ32547 and SWO2, which have been identified as potent oral active anti-hypertensive agents [12]. In addition, several alkaloids isolated from marine sources that contain the dihydropyrimidine core unit have shown interesting biological properties [13]. In particular, Batzelladine alkaloids have been found to be potent HIV gp-120-CD4 inhibitors [14]. Therefore, the synthesis of DHPM derivatives has gained prominence in synthetic organic as well as medicinal chemistry.

The Biginelli reaction, first described by the Italian chemist Pietro Biginelli [15] in 1893, involves the one-pot condensation of an aldehyde, a $\beta$-ketoester, and urea or thiourea under strongly acidic conditions. The harsh reaction conditions, long reaction time, and low yields when using substituted aromatic and aliphatic aldehydes are its main drawbacks. Hence the

* Corresponding author. Tel/Fax: +98-273-3395441; E-mail: akeivanloo@yahoo.com; keivanloo@shahroodut.ac.ir 
original Biginelli condensation was not suitable for compounds with sensitive functional groups.

Over the past few years, significant efforts have been made to find new procedures to produce DHPMs in good yields. However, most of the reported procedures have low reaction yields [16]. A large number of optimized procedures have been reported where most of the protocols employ catalytic methods in order to synthesize DHPMs [17-22]. These protocols utilize Lewis acids or metal-based catalysts such as $\mathrm{NiCl}_{2} \cdot 6 \mathrm{H}_{2} \mathrm{O}$, p-TsOH, $\mathrm{LaCl}_{3} \cdot 7 \mathrm{H}_{2} \mathrm{O}, \mathrm{BF}_{3} \cdot \mathrm{OEt}_{2}, \mathrm{InBr}_{3}, \mathrm{LiClO}_{4}, \mathrm{FeCl}_{3}, \mathrm{InCl}_{3}$, and metal triflates [23-31]. However, these often require relatively harsh reaction conditions such as high reaction temperature, expensive or highly acidic catalysts, and prolonged reaction time. In most cases, a stoichiometric amount of the catalyst is required to achieve good yields. In addition, most of the reactions require tedious work-up procedures and column purification, which ultimately result in diminished yields. Hence, the development of a new method that gives substituted DHPMs by an efficient and convenient procedure is of interest.

\section{Experimental}

All the reagents used were general reagent grade. The IR spectra were obtained with potassium bromide pellets or solvent in the range of $400-4000 \mathrm{~cm}^{-1}$ on a Shimadzu Model 460 pectrometer. The ${ }^{1} \mathrm{H}$ NMR spectra were recorded on a Brucker BRX 400 AVANCE spectrometer. The elemental analyses were performed on a Thermo Finnigan Flash EA microanalyzer. Powder X-ray diffraction (XRD) was carried out on a Philips PW1800 diffractometer.

\subsection{Preparation of the catalyst}

Boehmite nanoparticles were prepared according to Refs. [32-34] by the following procedure. Aluminum-2-butoxide (2 $\mathrm{mol} / \mathrm{L}, 10 \mathrm{~mL}$ ) in 2-butanol was placed in a $300 \mathrm{~mL}$ stainless steel autoclave that contained $50 \mathrm{~mL}$ of deionized water. The autoclave was heated for $5 \mathrm{~h}$ at $100{ }^{\circ} \mathrm{C}$ in an oven. After cooling the autoclave, the powder produced was filtered off and dried at $100{ }^{\circ} \mathrm{C}$ overnight. This powder was used as the catalyst in the organic reactions.

2.2. General procedure for the synthesis of 3,4-dihydropyrimidin-2-(1H)-ones and thiones under solvent-free conditions

To a mixture of aromatic aldehyde (1 mmol), a 1,3-dicarbonyl compound ( $1 \mathrm{mmol}$ ) and urea or thiourea (1.5 $\mathrm{mmol})$ in a test tube was added the boehmite nanoparticles (10 mol\%). The resulting mixture was heated with stirring at 120 ${ }^{\circ} \mathrm{C}$ for an appropriate time. The progress of reaction was monitored by TLC. At the end of the reaction, after cooling, the reaction mixture was washed with water to remove excess urea or thiourea. The crude product was dried and an execess amount of hot ethanol was added to it, and it was filtered to remove the catalyst. After evaporation of the solvent, the residue was crystallized from ethanol to afford the pure product.

The structures of the compounds were characterized by spectroscopic data and elemental analysis by the comparison of their spectroscopic data and physical properties with those reported in the literature. The characterization data for the synthesized compounds are given below.

5-Acetyl-6-methyl-4-(2,6-dichlorophenyl)-3,4-dihydropyrimidin-2(1H)-thione (4n). $\mathrm{mp}=226-228^{\circ} \mathrm{C} .{ }^{1} \mathrm{H} \mathrm{NMR}(400 \mathrm{MHz}$, $\mathrm{d}_{6}$-DMSO): $\delta 2.10\left(\mathrm{~s}, 3 \mathrm{H}, \mathrm{CH}_{3}\right), 2.22\left(\mathrm{~s}, 3 \mathrm{H}, \mathrm{CH}_{3}\right), 6.17(\mathrm{~s}, 1 \mathrm{H}, \mathrm{CH})$, $7.29(\mathrm{t}, J=8 \mathrm{~Hz}, 1 \mathrm{H}, \mathrm{CH}), 7.42(\mathrm{~d}, J=8 \mathrm{~Hz}, 2 \mathrm{H}, 2 \mathrm{CH}), 9.49(\mathrm{~s}, 1 \mathrm{H}$, $\mathrm{NH}), 10.23$ (s, 1H, NH); ${ }^{13} \mathrm{C}$ NMR (100 MHz, d6-DMSO): $\delta 18.29$, 30.90, 52.67, 107.96, 129.34, 129.67, 135.51, 136.30, 144.40, 173.52, 194.57. IR (KBr): 3168, 1632, 1571, 1433, 1321, 1117, $777 \mathrm{~cm}^{-1}$. Anal Calcd. for $\mathrm{C}_{13} \mathrm{H}_{12} \mathrm{Cl}_{2} \mathrm{~N}_{2} \mathrm{OS}$ : C, 49.53; $\mathrm{H}, 3.84 ; \mathrm{N}$, 8.89; S, 10.17; Found: C, 49.45; H, 3.80; N, 8.97; S, 10.22 .

5-Acetyl-6-methyl-4-(2-fluorophenyl)-3,4-dihydropyrimidin -2(1H)-thione (4s). mp $=208-210{ }^{\circ} \mathrm{C} .{ }^{1} \mathrm{H} \mathrm{NMR}(400 \mathrm{MHz}$, $\mathrm{d}_{6}$-DMSO): $\delta 2.18\left(\mathrm{~s}, 3 \mathrm{H}, \mathrm{CH}_{3}\right), 2.30\left(\mathrm{~s}, 3 \mathrm{H}, \mathrm{CH}_{3}\right), 5.52(\mathrm{~s}, 1 \mathrm{H}, \mathrm{CH})$, 7.12-7.25 (m, 3H, 3CH), 7.28-7.30 (m, 1H, CH), $9.62(\mathrm{~s}, 1 \mathrm{H}, \mathrm{NH})$, $10.28(\mathrm{~s}, 1 \mathrm{H}, \mathrm{NH}) ;{ }^{13} \mathrm{C}$ NMR $\left(100 \mathrm{MHz}, \mathrm{d}_{6}-\mathrm{DMSO}\right): \delta 18.89$, 32.15, 50.21, 108.04, 116.53, 126.16, 130.05, 131.17, 132.76, 148.65, 153.67, 175.21, 194.95. IR (KBr): 3312, 3200, 1615, 1580, 1480, 1450, 1320, 1180, $759 \mathrm{~cm}^{-1}$. Anal. Calcd. for $\mathrm{C}_{13} \mathrm{H}_{13} \mathrm{FN}_{2} \mathrm{OS}$ : C, 59.07; H, 4.96; N, 10.60; S, 12.13; Found: C, 59.19; H, 4.90; N, 10.50; S, 12.22 .

\section{Results and discussion}

In this continuation of our studies on the synthesis of heterocyclic compounds [35-38] and its methodology [39-42], we investigated the synthesis of DHPMs and thiones by the use of a solid catalyst under thermal or microwave and solvent-free conditions. Here, we report a mild and efficient one-pot protocol for the synthesis of substituted 3,4-dihydropyrimidin-2$(1 H)$ - one and thione derivatives by a multicomponent reaction involving a 1,3-dicarbonyl compound, an aldehyde, and urea or thiourea using boehmite nanoparticles as the catalyst under solvent-free conditions (Scheme 1).

Boehmite is an aluminum oxide hydroxide $(\gamma-\mathrm{AlOOH}) \mathrm{min}-$ eral. It is a component of the aluminium ore bauxite and contains extra hydroxyl groups on its surface. Among the different

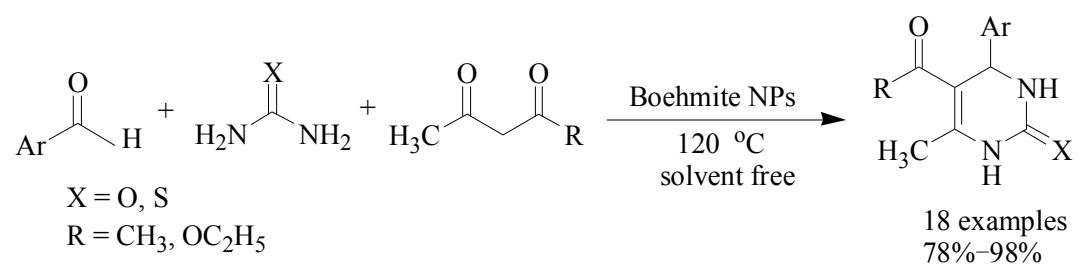

Scheme 1. Synthesis of substituted 3,4-dihydropyrimidin-2(1H)-ones or thions by a multicomponent reaction of aldehydes, 1,3-dicarbonyl compounds, and urea or thiourea in the presence of boehmite nanoparticles under solvent-free conditions. 
methods used for the preparation of boehmite nanoparticles, the hydrothermal sol-gel technique has the advantages of preparation in a one-pot process and low temperature processing. The most promising property of this hydrothermally produced nanoboehmite is the formation of it as a highly crystalline single phase product with no organic residue [32-34]. This was shown by its IR spectrum and XRD pattern, shown in Figs. 1 and 2, respectively.

The acidic sites of boehmite are shown in Fig. 3. The bridged and terminal surface hydroxyl groups of boehmite give two different stretching vibrations at 3280 and $3075 \mathrm{~cm}^{-1}$ in the IR spectrum. Boehmite also has some $\mathrm{Al}-\mathrm{O}$ related vibrations at $1150,1075,740,610$, and $480 \mathrm{~cm}^{-1}$.

The XRD pattern of the catalyst prepared also confirmed the crystallization as a single phase boehmite. The calculation of the particle size from the XRD pattern using the Scherer equation showed $10 \mathrm{~nm}$ particles. The surface area of the boehmite nanoparticles was $326 \mathrm{~m}^{2} / \mathrm{g}$.

In order to optimize the reaction conditions for the synthesis of DHPMs and thiones, the reaction of benzaldehydes with ethyl acetoacetate and urea was used as a model reaction. Reactions in different solvents, at different temperatures, and with various amounts of catalyst revealed that the best conditions were solvent-free at $120^{\circ} \mathrm{C}$ and $10 \mathrm{~mol} \%$ of boehmite nanoparticles (enry 8, Table 1).

To study the scope of the method, the reactions of a variety of aldehydes with ethyl acetoacetate and urea were performed,

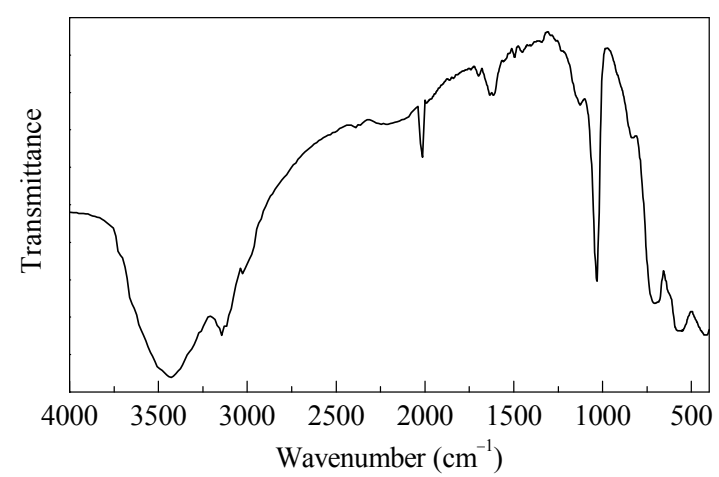

Fig. 1. IR spectrum of the boehmite nanoparticles prepared by a hydrothermal sol-gel process at $100{ }^{\circ} \mathrm{C}$.

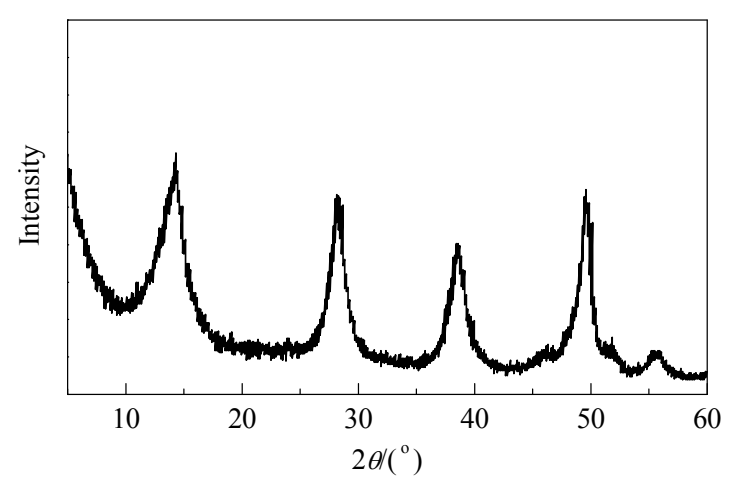

Fig. 2. XRD pattern of the boehmite nanoparticles prepared by a hydrothermal sol-gel process at $100^{\circ} \mathrm{C}$.

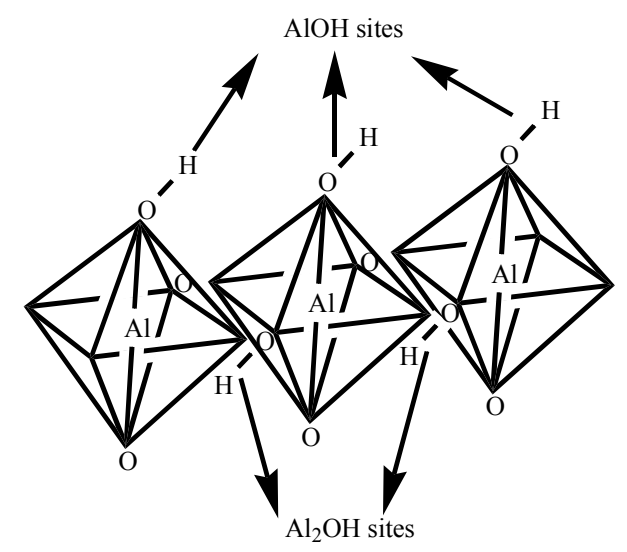

Fig. 3. Bridged and terminal hydroxyl groups of boehmite.

and a library of substituted DHPMs was obtained (Table 2).

Both electron-withdrawing and electron-donating substituents on the aldehyde aryl ring were tolerated well. Methyl-, methoxy-, nitro-, fluoro-, chloro-, and dichlorobenzaldehydes produced the desired products in high yields. The position of the substituent had no significant effect on the yield.

Next we replaced ethyl acetoacetate with acetylacetone, and we were pleased to find that the boehmite nanoparticles also catalyzed these reactions and afforded the DHPMs in quantitative yield. When we used thiourea instead of urea, 3,4-dihydropyrimidin-2- $(1 H)$-thiones were formed in high yields although the reaction time was prolonged.

Table 1

Condensation of benzaldehyde, ethylacetoacetate, and urea using different amounts of boehmite nanoparticles and solvents under thermal or microwave conditions.

\begin{tabular}{|c|c|c|c|c|c|c|}
\hline Entry & Solvent & $\begin{array}{l}\text { Catalyst loading } \\
\text { (mol\%) }\end{array}$ & $\begin{array}{l}\text { Time } \\
\text { (min) }\end{array}$ & $\begin{array}{c}\text { Temperature } \\
\left({ }^{\circ} \mathrm{C}\right)\end{array}$ & Condition & $\begin{array}{c}\text { Yeild }^{a} \\
(\%)\end{array}$ \\
\hline 1 & $\mathrm{EtOH}$ & 10 & 300 & 80 & Thermal & 10 \\
\hline 2 & EtOH & 20 & 300 & 80 & Thermal & 8 \\
\hline 3 & $\mathrm{CH}_{3} \mathrm{CN}$ & 10 & 300 & 80 & Thermal & 21 \\
\hline 4 & $\mathrm{CH}_{3} \mathrm{CN}$ & 20 & 300 & 80 & Thermal & 17 \\
\hline 5 & $\mathrm{H}_{2} \mathrm{O}$ & 10 & 300 & 100 & Thermal & 5 \\
\hline 6 & $\mathrm{H}_{2} \mathrm{O}$ & 20 & 300 & 100 & Thermal & 7 \\
\hline 7 & Neat & 10 & 20 & 100 & Thermal & 71 \\
\hline 8 & Neat & 10 & 5 & 120 & Thermal & 94 \\
\hline 9 & Neat & 10 & 5 & 140 & Thermal & 90 \\
\hline 10 & Neat & 5 & 5 & 120 & Thermal & 75 \\
\hline 11 & Neat & 3 & 5 & 120 & Thermal & 70 \\
\hline 11 & Neat & 20 & 3 & 120 & Thermal & 65 \\
\hline 12 & Neat & 10 & 4 & - & $\begin{array}{c}\text { Microwave } \\
(400 \mathrm{~W})\end{array}$ & 42 \\
\hline 13 & Neat & 10 & 6 & - & $\begin{array}{l}\text { Microwave } \\
(600 \mathrm{~W})\end{array}$ & 75 \\
\hline 14 & Neat & 10 & 8 & - & $\begin{array}{c}\text { Microwave } \\
(700 \mathrm{~W})\end{array}$ & 53 \\
\hline
\end{tabular}

Reaction conditions: aldehyde (1.0 mmol), 1,3-dicarbonyl compound (1.0 mmol), urea/thiourea (1.5 mmol), catalyst and solvent $(10 \mathrm{~mL})$. a Isolated yield. 
Table 2

Synthesis of 3,4-dihydropyrimidin-2-(1H)-ones and thiones under solvent-free conditions catalyzed by boehmite nanoparticles.

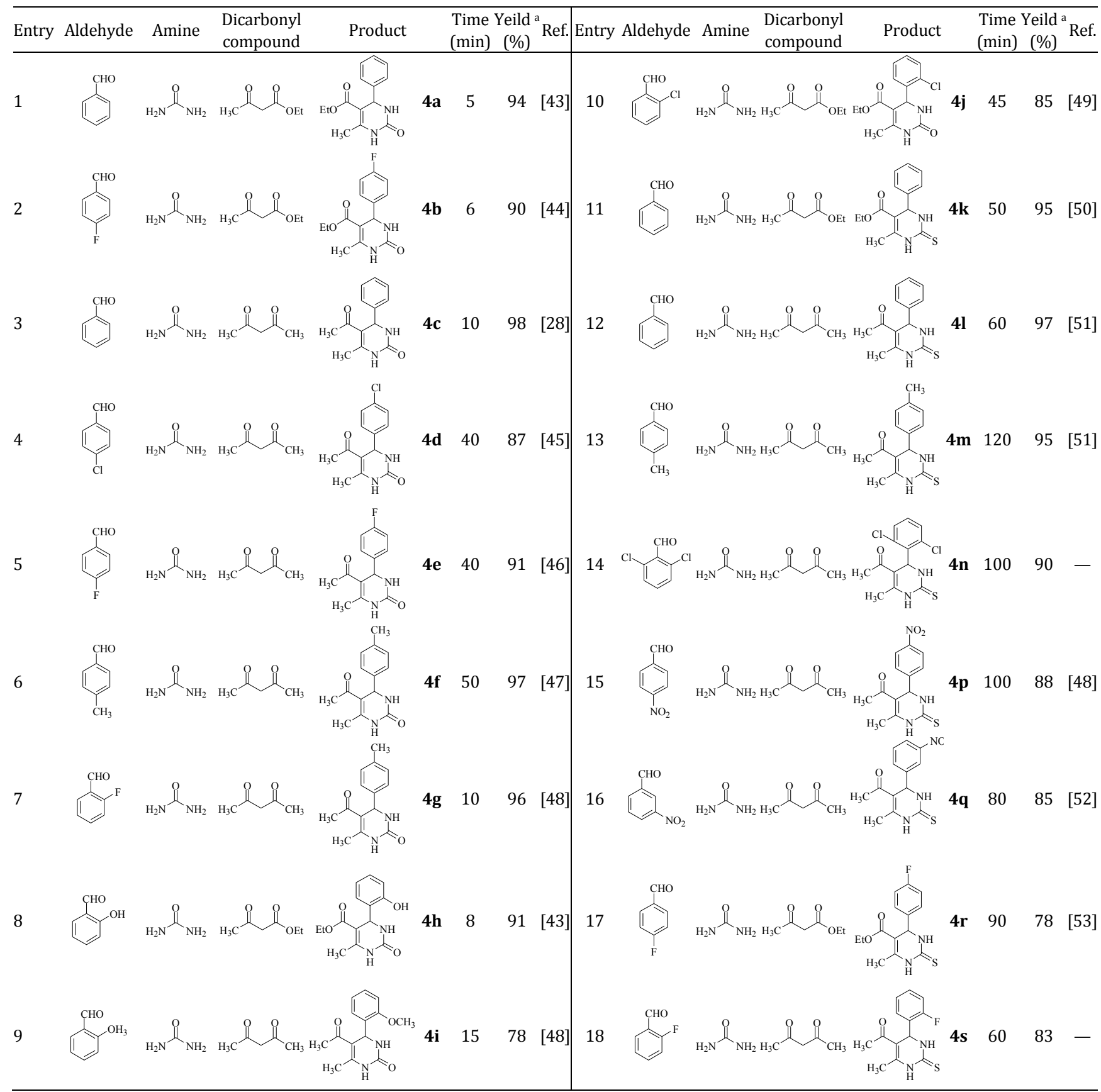

Reaction conditions: aldehyde (1.0 mmol), 1,3-dicarbonyl compound (1.0 mmol), urea/thiourea $(1.5 \mathrm{mmol})$, boehmite NPs (10 mol\%), $120{ }^{\circ} \mathrm{C}$. a Isolated yield.

The mechanism for the synthesis of DHPMs in the presence of the boehmite nanoparticle catalyst is shown in Scheme 2. The reaction proceeds via the acyl imine intermediate, which is formed by the reaction of aromatic aldehyde with urea or thiourea, with the aldehydic carbonyl group being activated by the acidic hydroxyl groups on the surface of boehmite nanoparticles by intermolecular hydrogen bonding. The reaction of this imine intermediate with ethyl acetoacetate produces an open chain ureide [30], which subsequently cyclizes to form the desired product.
Each compound can be isolated by crystallization, which avoids tedious work-up and column purification. The products were characterized by spectroscopic data and elemental analysis.

The reusability of the catalyst was also examined (Table 3). After each run, DMF was added, and the product was filtered. The residue (catalyst) was washed with $\mathrm{CHCl}_{3}$ and reused. The treatment with $\mathrm{CHCl}_{3}$ removed tars more efficiently from the catalyst surface. This catalyst was reusable, although a gradual decline in its activity was observed. 


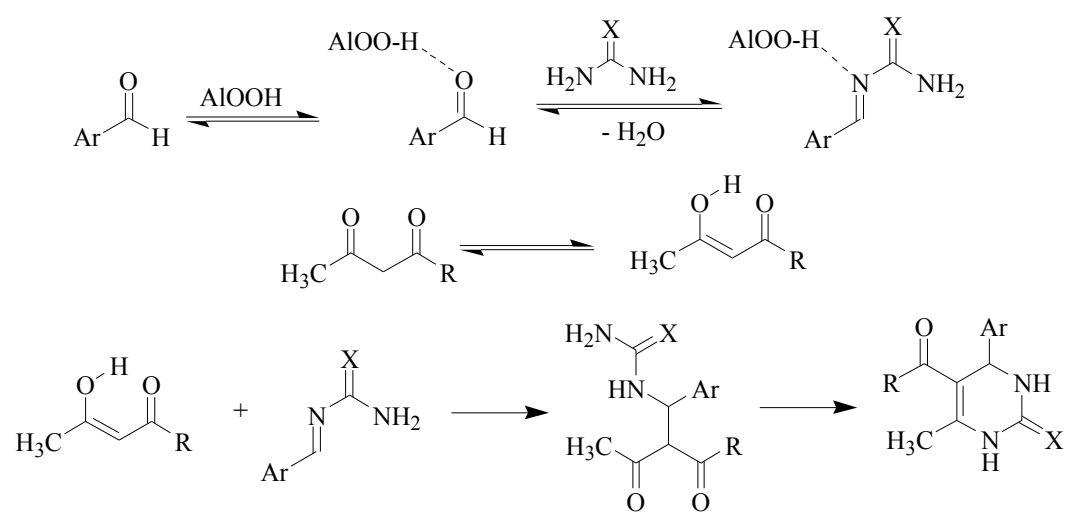

Scheme 2. Mechanism for the formation of 3,4-dihydropyrimidin-2(1H)-ones/thions by a multicomponent reaction of aldehydes, 1,3-dicarbonyl compounds, and urea or thiourea in the presence of boehmite nanoparticles.

\section{Table 3}

Condensation of benzaldehyde, ethylacetoacetate and urea using recycled catalysts.

\begin{tabular}{lcc}
\hline Number of cycles & Time $(\mathrm{min})$ & Yeild $^{\mathrm{a}}(\%)$ \\
\hline 1 & 10 & 92 \\
2 & 20 & 88 \\
3 & 30 & 85 \\
5 & 30 & 80 \\
\hline
\end{tabular}

Reaction conditions: aldehyde $(1.0 \mathrm{mmol})$, ethylacetoacetate $(1.0$ $\mathrm{mmol})$, urea (1.5 mmol), boehmite NPs $(10 \mathrm{~mol} \%), 120^{\circ} \mathrm{C}$.

a Isolated yield.

\section{Conclusions}

We developed an efficient, clean, and environmentally friendly procedure to produce DHPMs and thiones in good to high yields using MCRs. The protocol utilizes boehmite nanoparticles as the catalyst, uses mild reaction conditions, and does not require work-up or column purification. This green methodology can synthesize new substituted DHPM and thione scaffolds with biological applications.

\section{Acknowledgements}

The authors would like to thank the Research Council of Shahrood University of Technology for the financial support of this work.

\section{References}

[1] Cariou C C A, Clarkson G J, Shipman M. J Org Chem, 2008, 73: 9762

[2] Zhou L, Bohle D S, Jiang H F, Li C J. Synlett, 2009: 937

[3] Mukhopadhyay C, Tapaswi P K, Drew M G B. Tetrahedron Lett, 2010, 51: 3944

[4] Bonfield E R, Li C J. Adv Synth Catal, 2008, 350: 370

[5] Zhu J P. Eur J Org Chem, 2003: 1133

[6] Chapman C J, Frost C G. Synthesis, 2007: 1

[7] Wang L M, Sheng J, Zhang L, Han J W, Fan Z Y, Tian H, Qian C T. Tetrahedron, 2005, 61: 1539

[8] Atwal K S, Swanson B N, Unger S E, Floyd D M, Moreland S, Hedberg A, O’Reilly B C.J Med Chem, 1991, 34: 806

[9] Rovnyak G C, Kimball S D, Beyer B, Cucinotta G, DiMarco J D, Gougoutas J, Hedberg A, Malley M, McCarthy J P, Zhang R, Moreland S. J Med Chem, 1995, 38: 119
[10] Atwal K S, Rovnyak G C, Kimball S D, Floyd D M, Moreland S, Swanson B N, Gougoutas J Z, Schwartz J, Smillie K M, Malley M F. J Med Chem, 1990, 33: 2629

[11] Kappe C 0, Shishkin O V, Uray G, Verdino P. Tetrahedron, 2000, 56: 1859

[12] Kappe C O. Eur J Med Chem, 2000, 35: 1043

[13] Butters M, Davies C D, Elliott M C, Hill-Cousins J, Kariuki B M, Doi L L, Wood J L, Wordingham S V. Org BiomolChem, 2009, 7: 5001

[14] Heys L, Moore C G, Murphy P. J Chem Soc Rev, 2000, 29: 57

[15] Biginelli P. Gazz Chim Ital, 1893, 23: 360

[16] Lu J, Bai Y J. Synthesis, 2002: 4660

[17] Fesenko A A, Solovyev P A, Shutalev A D. Tetrahedron, 2010, 66: 940

[18] Tamaddon F, Razmi Z, Jafari A A. Tetrahedron Lett, 2010, 51: 1187

[19] Shen Z L, Xu X P, Ji S J. J Org Chem, 2010, 75: 1162

[20] Singh K, Singh S. Tetrahedron, 2009, 65: 4106

[21] Suzuki I, Iwata Y, Takeda K. Tetrahedron Lett, 2008, 49: 3238

[22] Schmidt R J, Lombardo L J, Traeger S C, Williams D K. Tetrahedron Lett, 2008, 49: 3009

[23] Fu N Y, Yuan Y F, Cao Z, Wang S W, Wang J T, Peppe C. Tetrahedron, 2002, 58: 4801

[24] Hu E H, Slider D R, Dolling U H. J Org Chem, 1998, 63: 3454

[25] Khabazzadeh H, Saidi K, Sheibani H. Bioorg Med Chem Lett, 2008, 18: 278

[26] Varala R, Alam M M, Adapa S R. Synlett, 2003: 67

[27] Paraskar A S, Dewkar G K, Sudalai A. Tetrahedron Lett, 2003, 44: 3305

[28] Ma Y,Qian C T, Wang L M, Yang M. J Org Chem, 2000, 65: 3864

[29] Yadav J S, Reddy B V S, Srinivas R, Venugopal C, Ramalingam T. Synthesis, 2001: 1341

[30] Li N, Chen X H, Song J, Luo S W, Fan W, Gong L Z. J Am Chem Soc, 2009, 131: 15301

[31] Chen X H, Xu X Y, Liu H, Cun L F, Gong L Z. J Am Chem Soc, 2006, 128: 14802

[32] Amini M M, Mirzaee M. J Sol-Gel Sci Technol, 2005, 36: 19

[33] Mirzaee M, Amini M M, Sadeghi M, Mousavi F Y, Sharbatdaran M. Ceram Silikaty, 2005, 49: 40

[34] Kharat A N, Mirzaee M, Amini M M. Asian J Chem, 2008, 20: 915

[35] Keivanloo A, Bakherad M, Nasr-Isfahani H, Esmaily S. Tetrahedron Lett, 2012, 53: 3126

[36] Bakherad M, Keivanloo A, Jajarmi S. Tetrahedron, 2012, 68: 2107

[37] Keivanloo A, Bakherad M, Rahimi A. Synthesis, 2010: 1599

[38] Bakherad M, Nasr-Isfahani H, Keivanloo A, Doostmohammadi N. Tetrahedron Lett, 2008, 49: 3819

[39] Bakherad M, Keivanloo A, Samangooei S. Tetrahedron Lett, 2012, 53: 5773 


\section{Graphical Abstract}

Chin. J. Catal., 2014, 35: 362-367 doi: 10.1016/S1872-2067(12)60759-1

Boehmite nanoparticle catalyst for the one-pot multicomponent synthesis of 3,4-dihydropyrimidin-2-(1H)-ones and thiones under solvent-free conditions

Ali Keivanloo*, Mahdi Mirzaee, Mohammad Bakherad, Atena Soozani Shahrood University of Technology, Iran

Boehmite nanoparticles are a highly active and green catalyst for the synthesis of highly substituted 3,4-dihydropyrimidin-2-( $1 H)$-ones and thiones under solvent-free conditions.

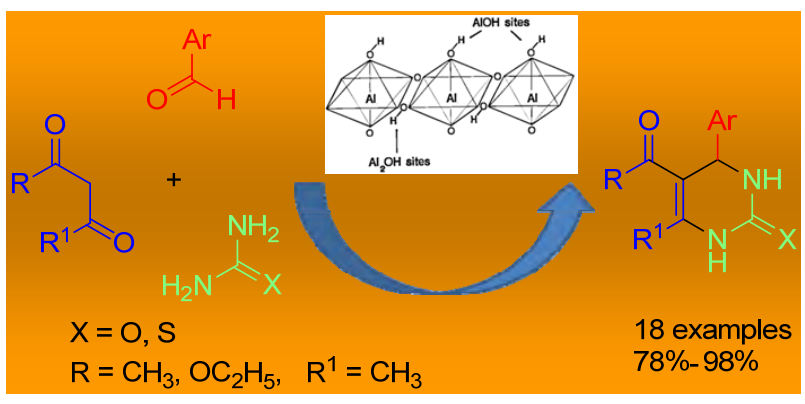

[40] Keivanloo A, Bakherad M, Bahramian B, Rahmani M, Taheri S A N. Synthesis, 2011: 325

[41] Keivanloo A, Bakherad M, Bahramian B, Baratnia S. Tetrahedron Lett, 2011, 52: 1498

[42] Bakherad M, Keivanloo A, Bahramian B, Jajarmi S. Appl Catal A, 2010, 390: 135

[43] Ramu E, Kotra V, Bansal N, Varala R, Adapa S R. Rasayan J Chem, 2008, 1: 188

[44] Karade H N, Sathe M, Kaushik M P. Molecules, 2007, 12: 1341

[45] Maradur S P, Gokavi G S. Catal Commun, 2007, 8: 279

[46] Chitra S, Pandiarajan K. Tetrahedron Lett, 2009, 50: 2222

[47] Bigdeli M A, Jafari S, Mahdavinia G H, Hazarkhani H. Catal Com-

mun, 2007, 8: 1641

[48] Shaterian H R, Hosseinian A, Ghashang M, Khorami F, Karimpoor N. Phosphorous Sulfur Silicon Relat Elem, 2009, 184: 2333

[49] Zumpe F L, Fluess M, Schmitz K, Lender A. Tetrahedron Lett, 2007, 48: 1421

[50] Rodriguez-Dominguez J C, Bernardi D, Kirsch G. Tetrahedron Lett, 2007, 48: 5777

[51] Shete D K, Surve S S, Patil S B, Narade S B, Patil K S, Pore Y V. Der Pharmacia Lettre, 2010, 2(3): 59

[52] Sangshetti J N, Kokare N D, Shinde D B. J Heterocycl Chem, 2008, 45: 1191

[53] Chitra S, Devanathan D. Arch Appl Sci Res, 2012, 4: 1716 